7. Иванов О. В., Иванов О. Ю. Рекомендации по практической диагностике и оздоровлению стад крупного рогатого скота от лейкоза. Farm Animals. 2015. № 1. С. 22-24.

8. Зубова Т. В., Плешков В. А., Миронов А. Н. Современные методы и опыт борьбы с лейкозом крупного рогатого скота. Siberian Journal of Life Sciences and Agriculture. 2018. T. 10, № 5. C. 119-131.

9. І Інструкція з профілактики та оздоровлення великої рогатої худоби від лейкозу : затв. наказом Держ. ком. вет. медицини України 21.12.2007, № 21 ; зареєстр. в Мінюсті України 11.01.2008 р., № 12/14703. Київ, 2008. 8 с.

\title{
CURRENT APPROACHES TO THE LIVESTOCK RECOVERY FROM CATTLE LEUKEMIA
}

Korneikov O. M., Gorbatenko S. K., Zagorodniy A. I., Stegniy B. T.

National Scientific Center "Institute of Experimental and Clinical Veterinary Medicine", Kharkiv, Ukraine

\section{Mandyhra M. S. \\ National Academy of Agrarian Sciences of Ukraine, Kyiv, Ukraine}

The purpose of the work was to determine the effectiveness of different approaches to the recovery of cattle population from leukemia, and their impact on cattle productivity and profitability of livestock farming. The choice of measures to ensure the safety of a particular farm was determined by indicators of herd infection, number of livestock population in the holding, availability of conditions for isolated keeping of animals, availability of herd replacements. Two methods of serological testing were used during the work, namely ID and ELISA. The methodological basis of the work was the regular serological examination of conditionally safe concerning leukemia livestock in the ID - once every 20-30 days, or by ELISA - with an interval of 45-50 days. According to the results of each study, depending on the approach of farm recovery, infected with leukemia animals were slaughtered or isolated from the herd in an isolated group. Improvement of farms by detecting and slaughtering infected animals is economically justified only in the case of livestock infections up to 5-10\%. In other cases, it is advisable to carry out rehabilitation by the method of gradual replacement of the infected livestock, which allows to ensure the safety of the farms during 2-4 years while saving the population and productivity of the livestock recovery

Keywords: immunodiffusion test (ID), enzyme-linked immunosorbent assay (ELISA), cattle productivity,

\section{ДОСЛІДЖЕННЯ ЕПІЗООТИЧНИХ СИРОВАТОК КРОВІ ЖУЙНИХ ТВАРИН У РЕАКЦІЇ ЗВ'ЯЗУВАННЯ КОМПЛЕМЕНТУ (РЗК) 3 ПАРАТУБЕРКУЛЬОЗНИМ АНТИГЕНОМ}

\author{
Завгородній А. І., Позмогова С. А., Гончарова Н. В., Калашник М. В., Білушко В. В. \\ Національний науковий центр «Інститут експериментальної і клінічної \\ ветеринарної медицини», Харків, Україна, e-mail: nick.v.kalashnik@gmail.com
}

У статті наведені результати дослідження епізоотичних проб сироваток крові від великої та дрібної рогатої худоби у реакції зв'язування комплементу з паратуберкульозним антигеном, який виготовлений у лабораторії вивчення туберкульозу ННЦ «ІЕКВМ» із культурального фрільтрату M. avium subsp. paratuberculosis (MAP). У реакції зв'язування комплементу було досліджено 1098 сироваток крові з 19 господарств 9 областей України, а також 24 сироватки крові від дрібної рогатої худоби, отриманих із 2 господарств, які розташовані у Харківській та Одеській областях. За результатами проведених досліджень у РЗК специфрічні до МАР антитіла були виявлені у 17 пробах сироваток крові від великої рогатої худоби у діагностичному титрі 1:10, а в 9 пробах отримано сумнівний результат. У сироватках крові від дрібної рогатої худоби антитіл до МАР не було виявлено

Ключові слова: антиген, велика рогата худоба, дрібна рогата худоба, паратуберкульоз, реакція зв'язування комплементу, сироватки крові

Паратуберкульоз (паратуберкульозний ентерит, хвороба Йоне) - хронічне захворювання жуйних тварин, спричинене Mycobacterium avium subsp. paratuberculosis (MAP), яке характеризується повільним розвитком продуктивного гранулематозного ентериту, діареєю, втратою продуктивності, кахексією та загибеллю тварин. В інфікованих тварин 
паратуберкульозний ентерит має тривалий латентний період до 5-6 років. Лікування хворих тварин у більшості випадків $є$ неефективним та економічно необґрунтованим.

Клінічні симптоми та патологоанатомічні зміни при паратуберкульозі вперше були описані H. A. Johne та L. Frothingham протягом XIX сторіччя. Проведеними дослідженнями у 1906 р. B. Bang встановив різницю між туберкульозом і нетуберкульозним ентеритом i запропонував останній називати псевдотуберкульозним ентеритом. F. W. Twort у 1912 р. провів ідентифрікацію етіологічного агенту, виділеного від хворих тварин, та охарактеризував збудника, який зумовлював експериментальний ентерит у великої рогатої худоби. Пізніше збудника було віднесено до роду Mycobacterium підвиду Mycobacterium paratuberculosis, а захворювання здобуло назву паратуберкульоз [1, 2].

У середині XX століття паратуберкульозна інфекція набула помітного поширення та розповсюдження у багатьох країнах світу, особливо в молочних гуртах великої рогатої худоби, що суттєво впливало на економічні показники у тваринницьких господарствах. Так, у Сполучених Штатах Америки економічні збитки від цієї хвороби щорічно складають від 200-250 мільйонів [3] до 1,5 мільярда доларів [4]. Разом з цим багато закордонних авторів відмічають значний вплив цього захворювання на світову економіку [1, 5-8]. В останні роки розповсюдженість цього захворювання в різних країнах варіює від спорадичних випадків до 70,0 \% інфрікованого поголів'я в неблагополучних гуртах $[9,10]$.

За даними OIE World Animal Health Information System у 2018 р. клінічні випадки хвороби в гуртах великої рогатої худоби реєстрували в Афрганістані, Аргентині, Австрії, Великобританії, Угорщині, Німеччині, Греції, Данії, Єгипті, Іспанії, Ірані, Ірландії, Ізраїлі, Канаді, Катарі, Кіпрі, Китаї, Колумбії, Кореї, Коста Ріці, Лівії, Люксембурзі, Новій Зеландії, Саудівській Аравії, Словенії, США, Росії, Франції, Чилі, Швейцарії, Японії [11].

Починаючи з 70-х рp. XX століття поголів'я великої рогатої худоби України вважається благополучним щодо паратуберкульозної інфрекції. Разом з цим швидке розширення міжнародних зв'язків України несе загрозу занесення збудника паратуберкульозу до нашої держави 3 імпортованою молочною та м'ясною худобою, продукцією тваринного походження (м'ясо, молоко, сири), а також із генетичним матеріалом (сперма, ембріони).

Діагноз на паратуберкульоз встановлюють комплексно на основі епізоотологічних даних, характерних клінічних ознак і результатів алергічного, патологоанатомічного, культурального (висіви фекальних і тканинних проб) методів дослідження [12, 13]. Також для діагностики використовують серологічний (РЗК [14-18], РІД [16, 18-20], ІФА [17, 18, 21-23]), гістологічний методи, гамма-інтерфероновий тест, ДНК-тести: ПЦР (фекалії та тканини) [24].

Реакція зв'язування комплементу протягом багатьох років була стандартним тестом для діагностики паратуберкульозу у великої рогатої худоби. Відмічається велика ефективність цього тесту з сироватками крові від тварин, які мають клінічні ознаки хвороби. Менша специфрічність цього методу відмічається з сироватками крові тварин, в яких інфекційний процес має субклінічну форму перебігу. У багатьох країнах, які імпортують худобу, цей тест $€$ обов'язковим при диспансеризації тварин. У світі існує багато виробників тест-наборів для РЗК, але і дотепер немає еталонного зразка позитивної сироватки, яка б стандартизувала всі набори для міжнародного використання [24].

Багато закордонних авторів вважають найбільш ефективним методом прижиттєвої діагностики паратуберкульозу у сільськогосподарських тварин саме ІФА [18, 21, 23, 25, 26]. Але висока вартість імпортних тестових наборів і наявність хибно-позитивних реакцій створюють складнощі при використанні цього методу для проведення моніторингових досліджень щодо паратуберкульозу, зокрема і в господарствах України. За даними цих же авторів, РЗК лише незначною мірою поступається методу ІФА $[17,18]$. Тому в нашій роботі і був використаний саме метод РЗК з паратуберкульозним антигеном з культурального фільтрату (АКФ) і позитивною паратуберкульозною сироваткою крові кролів, які були розроблені в лабораторії вивчення туберкульозу ННЦ «ІЕКВМ».

Не дивлячись на те, що на сьогоднішній день поголів'я великої рогатої худоби в Україні офріційно вважається благополучним щодо паратуберкульозу, існує ймовірність занесення збудника та виникнення цього захворювання в господарствах, що комплектують стада імпортною худобою, а також генетичним матеріалом. Оскільки моніторингові діагностичні дослідження щодо цього захворювання у закуплених із-за кордону тварин у період карантинування в господарствах 
проводяться не у всіх випадках, і такі тварини вводяться в основне стадо, то виникає необхідність вивчення епізоотичної ситуації шляхом проведення комплексних досліджень поголів'я великої рогатої худоби.

Метою нашої роботи було дослідження польових сироваток крові від великої рогатої худоби у РЗК з паратуберкульозним антигеном АКФ для з'ясування епізоотичної ситуації щодо паратуберкульозу серед молочного поголів'я великої рогатої худоби у різних областях України.

Матеріали і методи досліджень. Для проведення досліджень у РЗК з паратуберкульозним антигеном досліджували сироватки крові від реагуючої на туберкулін (ППД) для ссавців великої рогатої худоби з благополучних щодо туберкульозу та паратуберкульозу господарств. Отримані від великої рогатої худоби сироватки крові переливали в пробірки типу епендорф. За необхідності сироватки піддавали заморожуванню в морозильній камері за температури мінус $18-20{ }^{\circ} \mathrm{C}$.

Дослідження отриманих сироваток крові у РЗК проводили згідно 3 методичними рекомендаціями «Лабораторна діагностика паратуберкульозу» (затв. НМР ДВФСУ пр. № 1 від 19.12.2014). Робочі розведення всіх компонентів для РЗК готували безпосередньо перед постановкою реакції. Для дослідження використовували компоненти, які не мають антикомплементарних та гемолітичних властивостей.

Контрольні сироватки (позитивну та негативну) досліджували у розведенні 1:10 з антигеном, а дослідні сироватки - в розведенні 1:5 та 1:10.

Усі сироватки крові, які використовували в досліді, інактивували на водяній бані за температури $61{ }^{\circ} \mathrm{C}$ протягом 30 хвилин. Зв'язування комплементу здійснювали 20 хвилин на водяній бані за температури $37^{\circ} \mathrm{C}$, після додавання гемолітичної системи пробірки витримували на водяній бані за температури $37^{\circ} \mathrm{C}$ упродовж 20 хвилин.

При постановці основного досліду ставили наступні контролі: 1) негативна та позитивна сироватки у розведеннях 1:5 та 1:10 з антигеном та 1:5 без антигену; 2) комплемент (0,2 мл комплементу + 0,2 мл суспензії еритроцитів + 0,6 мл фріз. розчину); 3 ) гемолітична система (0,2 мл комплементу + 0,4 мл фізіологічного розчину та 0,4 мл гемолітичної системи); 4) антиген у робочому титрі (0,2 мл комплементу $+0,2$ мл антигену $+0,4$ мл гем. системи + 0,2 мл фріз. розчину). Облік реакції проводили через 16-18 годин після постановки реакції за кімнатної температури в умовах, що виключають вплив прямого сонячного світла, тепла та інших чинників.

Результати реакції відмічали знаками «+» та «-»: 1) позитивна реакція: «++++» і «+++»; 2) сумнівна реакція: «++» і «+»; 3) негативна реакція: «-».

Результати досліджень. У РЗК було досліджено 1098 проб сироваток крові від великої рогатої худоби та 24 сироватки крові від дрібної рогатої худоби. Результати дослідження сироваток крові великої рогатої худоби на паратуберкульоз із 19 господарств 9 областей України, а також сироваток крові дрібної рогатої худоби із 2 господарств 2 областей представлені у таблиці.

Таблиця - Дослідження сироваток крові ВРХ і ДРХ у РЗК

\begin{tabular}{|c|c|c|c|c|c|}
\hline \multirow[b]{2}{*}{ Область } & \multirow{2}{*}{$\begin{array}{c}\text { Кількість } \\
\text { господарств }\end{array}$} & \multirow{2}{*}{$\begin{array}{c}\text { Кількість } \\
\text { досліджених } \\
\text { сироваток }\end{array}$} & \multicolumn{3}{|c|}{ Результати досліджень } \\
\hline & & & $\begin{array}{c}\text { Позитивні } \\
\text { (діагн. титр 1:10) }\end{array}$ & Сумнівні & Негативні \\
\hline \multicolumn{6}{|c|}{ Велика рогата худоба } \\
\hline Полтавська & 2 & 283 & 7 & 4 & 272 \\
\hline Харківська & 4 & 380 & - & - & 380 \\
\hline Черкаська & 3 & 34 & - & - & 34 \\
\hline Київська & 1 & 12 & - & - & 12 \\
\hline Донецька & 1 & 191 & 6 & 3 & 182 \\
\hline Кіровоградська & 3 & 29 & - & - & 29 \\
\hline Сумська & 2 & 127 & - & - & 127 \\
\hline Одеська & 1 & 10 & - & - & 10 \\
\hline Хмельницька & 2 & 32 & 4 & 2 & 26 \\
\hline \multicolumn{6}{|c|}{ Дрібна рогата худоба } \\
\hline Харківська & 1 & 20 & - & - & 20 \\
\hline Одеська & 1 & 4 & - & - & 4 \\
\hline
\end{tabular}


Із матеріалів, наведених у таблиці, видно, що при серологічному дослідженні сироваток крові, відібраних від реагуючої на туберкулін для ссавців великої рогатої худоби, у РЗК з паратуберкульозним антигеном у 17 пробах виявлені специфічні до МАР антитіла в діагностичних титрах (1:10) у тварин, які утримуються в 4 господарствах Полтавської, Донецької та Хмельницької областей. Разом з цим у 9 пробах сироваток крові інших тварин із цих господарств у РЗК отримано сумнівний результат. У сироватках крові від дрібної рогатої худоби паратуберкульозних антитіл у жодному випадку не виявлено.

При подальших спостереженнях у господарстві Хмельницької області через один рік у трьох тварин спостерігали клінічні ознаки паратуберкульозного ентериту. При діагностичному забої в однієї тварини в тонкому відділі кишечника були виділені характерні для паратуберкульозу ураження. У мазках із відібраного патологічного матеріалу виявляли кислотостійкі палички, які були розташовані поодиноко та групами.

Висновки. Результати проведених моніторингових досліджень свідчать про циркуляцію збудника M. avium subsp. paratuberculosis в окремих господарствах, що в майбутньому може ускладнити епізоотичну ситуацію щодо паратуберкульозу та сприяти поширенню збудника цього захворювання в інші благополучні господарства. 3 метою з'ясування, контролю епізоотичної ситуації в гуртах великої рогатої худоби та для запобігання поширення паратуберкульозу в благополучні господарства необхідно щорічно проводити серологічні моніторингові дослідження продуктивного поголів'я тварин, а також поголів'я, що імпортується в Україну для комплектування молочних гуртів.

\section{Список ліmepamypu}

1. Chiodini R. J. Ruminant paratuberculosis (Johne's disease): the current status and future prospects / R. J. Chiodini, H. J. Van Kruiningen, R. S. Merkal // The Cornell Veterinarian. - 1984. - Vol. 74, No. 3. - P. 218-262.

2. Kreeger J. M. Ruminant paratuberculosis-a century of progress and frustration / J. M. Kreeger // Journal of Veterinary Diagnostic Investigation : official publication of the American Association of Veterinary Laboratory Diagnosticians, Inc. - 1991. - Vol. 3, No. 4. - P. 373-382.

3. Wells S. J. Herd-level risk factors for infection with mycobacterium paratuberculosis in US dairies and association between familiarity of the herd manager with the disease or prior diagnosis of the disease in that herd and use of preventive measures / S. J. Wells, B. A. Wagner // Journal of the American Veterinary Medical Association. - 2000. Vol. 216, No. 9. - P. 1450-1457.

4. Stabel J. R. Johne's disease: a hidden threat / J. R. Stabel // Journal of Dairy Science. — 1998. — Vol. 81, No. 1. — P. 283-288.

5. Pandey G. S. Paratuberculosis (Johne's disease) in a herd of Friesian cattle in Zambia / G. S. Pandey, T. L. Musonda, H. G. Chizyuka, M. Schneebeli // The Veterinary Record. - 1987. — Vol. 120, No. 15. - P. 369.

6. Merkal R. S. Prevalence of mycobacterium paratuberculosis in ileocecal lymph nodes of cattle culled in the United States / R. S. Merkal, D. L. Whipple, J. M. Sacks, G. R. Snyder // Journal of the American Veterinary Medical Association. - 1987. - Vol. 190, No. 6. - P. 676-680.

7. Behymer D. E. Mass screening of cattle sera against 14 infectious disease agents, using an ELISA system for monitoring health in livestock / D. E. Behymer, H. P. Riemann, W. Utterback [et al.] // American Journal of Veterinary Research. - 1991. - Vol. 52, No. 10. - P. 1699-1705.

8. Sweeney R. W. Transmission of paratuberculosis / R. W. Sweeney // The Veterinary Clinics of North America. Food Animal Practice. - 1996. - Vol. 12, No. 2. - P. 305-312.

9. Nielsen S. S. A review of prevalences of paratuberculosis in farmed animals in Europe / S. S. Nielsen, N. Toft // Preventive Veterinary Medicine. - 2009. - Vol. 88, No. 1. - P. 1-14.

10. Lombard J. E. Epidemiology and economics of paratuberculosis / J. E. Lombard // Veterinary Clinics of North America. Food Animal Practice. - 2011. - Vol. 27, No. 3. - P. 525-535.

11. OIE World animal health information system / Weekly Animal Disease service global report. URL: http://www.oie.int/wahis_2/public/wahid.php/Countryinformation/Animalsituation. (Accessed: 10.06.2019).

12. Kim Y. G. Comparison of two methods for isolation of Mycobacterium paratuberculosis from bovine fecal samples / Y. G. Kim, S. Bech-Nielsen, J. C. Gordon [et al.] // American Journal of Veterinary Research. — 1989. — Vol. 50, No. 7. - P. 1110-1113.

13. Collins M. T. Enhanced radiometric detection of Mycobacterium paratuberculosis by using filter-concentrated bovine fecal specimens / M. T. Collins, K. B. Kenefick, D. C. Sockett [et al.] // Journal of Clinical Microbiology. - 1990. Vol. 28, No. 11. - P. 2514-2519.

14. De Lisle G. W. Bovine paratuberculosis in a comparison of fecal culture and the antibody response / G. W. de Lisle, B. S. Samagh, J. R. Duncan // Canadian Journal of Comparative Medicine. - 1980. — Vol. 44, No. 2. - P. 183191.

15. Larsen A. B. An extended study of a herd of cattle naturallyinfected with Johne's disease in the significance of the complement-fixation test / A. B. Larsen, T. H. Vardaman, R. S. Merkal // American Journal of Veterinary Research. 1963. - Vol. 24. - P. 948-950. 
16. Sherman D. M. Comparison of the complement-fixation and agar gel immunodiffusion tests for diagnosis of subclinical bovine paratuberculosis / D. M. Sherman, J. M. Gay, D. S. Bouley, G. H. Nelson // American Journal of Veterinary Research. - 1990. - Vol. 51, No. 3. - P. 461-465.

17. Kalis C. H. J. Evaluation of two absorbed enzyme-linked immunosorbent assays and a complement fixation test as replacements for fecal culture in the detection of cows shedding Mycobacterium avium subspecies paratuberculosis / C. H. J. Kalis, H. W. Barkema, J. W. Hesselink [et al.] // Journal of Veterinary Diagnostic Investigation. - 2002. Vol. 14, No. 3. - P. 219-224.

18. Sockett D. C. Evaluation of four serological tests for bovine paratuberculosis / D. C. Sockett, T. A. Conrad, C. B. Thomas, M. T. Collins // Journal of Clinical Microbiology - 1992. — Vol. 30, No. 5. - P. 1134-1139.

19. Sherman D. M. Evaluation of the agar gel immunodiffusion test for diagnosis of subclinical paratuberculosis in cattle / D. M. Sherman, B. Bray, J. M. Gay, F. Bates // American Journal of Veterinary Research. — 1989. — Vol. 50, No. 4. - P. 525-530.

20. Sherman D. M. Agar gel immunodiffusion test for diagnosis of clinical paratuberculosis in cattle / D. M. Sherman, R. J. Markham, F. Bates // Journal of the American Veterinary Medical Association. — 1984. — Vol. 185, No. 2. P. $179-182$.

21. Gümüşsoy K. S. Serological and molecular diagnosis of paratuberculosis in dairy cattle / K. S. Gümüşsoy, T. Iça, S. Abay [et al.] // Turkish Journal of Veterinary and Animal Sciences. - 2015. — Vol. 39, No. 2. - P. 147-153.

22. Fernández-Silva J. A. Diagnosis and molecular characterization of Mycobacterium avium subsp. paratuberculosis from dairy cows in Colombia / J. A. Fernández-Silva, A. Abdulmawjood, M. Bülte // Veterinary Medicine International. - 2011. - Vol. 2011. - P. 352561.

23. Collins M. T. Evaluation of five antibody detection tests for diagnosis of bovine paratuberculosis / M. T. Collins, S. J. Wells, K. R. Petrini [et al.] // Clinical and Diagnostic Laboratory Immunology. — 2005. — Vol. 12, No. 6. — P. 685-692.

24. Chapter 2.1.11. Paratuberculosis (Johne's disease) // Manual of Diagnostic Tests and Vaccines for Terrestrial Animals. $-6^{\text {th }}$ ed. - Paris : OIE, 2014. $-16 \mathrm{pp}$.

25. Norton S. Evaluation of diagnostic tests for Johne's disease (Mycobacterium avium subspecies paratuberculosis) in New Zealand dairy cows / S. Norton, W. O. Johnson, G. Jones, C. Heuer // Journal of Veterinary Diagnostic Investigation. - 2010. - Vol. 22, No. 3. - P. 341-351.

26. Miller D. S. Specificity of four serologic assays for Mycobacterium avium subspecies paratuberculosis in llamas and alpacas: a single herd study / D. S. Miller, M. T. Collins, B. B. Smith [et al.] // Journal of Veterinary Diagnostic Investigation. - 2000. - Vol. 12, No. 4. - P. 345-353.

\section{THE STUDY OF EPIZOOTIC SERA OBTAINED FROM RUMINANT ANIMALS IN COMPLEMENT FIXATION TEST (CFT) WITH THE USE OF PARATUBERCULOUS ANTIGEN}

\section{Zavgorodniy A. I., Pozmogova S. A., Goncharova N. V., Kalashnyk M. V., Bilushko V. V.}

National Scientific Center "Institute of Experimental and Clinical Veterinary Medicine", Kharkiv, Ukraine

The paper presents results of the study of epizootic blood sera in the complement fixation test (CFT) with paratuberculous antigen. Blood sera were sampled from the cattle and goats. The antigen was produced from the culture filtrate of Mycobacterium avium subspecies paratuberculosis (MAP) in the laboratory for tuberculosis study. The aim of the present study was to clarify the epizootic situation concerning Johne's disease among the dairy cattle in different regions of Ukraine. To achieve this aim the blood sera from cattle and goats were collected from farms in different regions of Ukraine. Those sera samples were studied in the complement fixation test with the use of paratuberculous antigen that was produced from the culture filtrate of MAP. The above mentioned blood sera were collected from the cattle that had positive allergic reactions on the use of tuberculin (PPD) for mammals. Those animals belonged to the free from tuberculosis and paratuberulosis milk farms. The study of obtained samples of blood sera was conducted in the accordance with the methodological guidelines "Laboratory diagnostics of paratuberculosis" (shutter. NMR FEFU pr. No. 1, dated December 19, 2014). There were studied 1098 blood sera samples from cattle. In addition to this, investigation was conducted on 24 samples of blood sera from goats. As the result of conducted study it was found that 17 samples of blood sera contained specific antibodies against MAP (serum solution 1:10). These blood sera collected from the cattle belonging to 4 farms in Poltava, Donetsk and Khmelnitsky regions. Along with this it was obtained 9 uncertain results in compliment fixation test that was conducted between paratuberculous antigen (ACF) and blood sera from those 4 farms. The results of monitoring studies indicate that $M$. avium subsp. paratuberculosis pathogen circulates in studied farms. This can lead to the complication of the epizootic situation regarding paratuberculosis and contribute to the spreading of this pathogen to other free from MAP infection farms. There are no anti-paratuberculosis antibodies in blood serum from goats. It is necessary to conduct annual monitoring serological studies of productive dairy cattle and imported animals in order to clarify and control epizootic situation concerning paratuberculosis on the territory of Ukraine blood sera

Keywords: antigen, cattle, goats, paratuberculosis (Johne's disease), complement fixation test (CFT), 